\title{
Students Perception Towards Challenges and Difficulties to Established E-learning Medical Education in a High Burden Developing Country
}

MOHAMED Daffalla Awadalla GISMALLA ( $\nabla$ mohadaff22@gmail.com )

University of Gezira Faculty of Medicine https://orcid.org/0000-0002-6081-0107

Mohamed Soud Mohamed

University of Gezira Faculty of Medicine

Mohammed NaserEldeen Mohamed

University of Gezira Faculty of Medicine

Moawia Mohamed Ali Elhassan

University of Gezira Faculty of Medicine

Omaima Ibrahim

University of Gezira Faculty of Medicine

\section{Research}

Keywords: E-learning, Medical Education, COVID-19, Student Perception, developing countries

Posted Date: July 17th, 2020

DOI: https://doi.org/10.21203/rs.3.rs-41972/v1

License: (c) (i) This work is licensed under a Creative Commons Attribution 4.0 International License. Read Full License 


\section{Abstract}

Background After World Health organization declaration of COVID-19 as a worldwide pandemic. Medical education, as well as general education, was stopped and ceased in developing countries which affect the education process, while in developed countries it was changed to E-learning models. This study aimed to highlight challenges and difficulties of E-learning beside the perception of students towards the effect of COVID19 in medical education.

Methods This is a cross-sectional survey study which conducted during 10-25 May 2020 to determine the perception of medical student regard the e-learning, COVID Pandemic related difficulties to reestablish the educational process. An online-based questionnaire was developed, and a pilot study was performed. Yes/No questions, four response questions in a form of strongly agree, agree, disagree, and strongly disagree (modified Likert scale) and open questions were used. Data were entered and analyzed using SPSS (Statistical Package for Social Science); version 24. Chi-square distribution was applied to assess the statistical significance of variables' $<0.05$ was considered as statistically significant.

Results This study revealed closure of the university is mandatory to prevent the spread of COVID-19, however, continuing education through E-learning tools is a crucial step. Additionally, it demonstrates the challenges and difficulties to establish E-learning such as internet service, facilities, technical support, live sessions, interactions and exam conductions.

Conclusion Students are willing to continue their learning and educational process. However, there are challenges and difficulties which need more analysis to overcome it.

\section{Introduction}

In March 2020 World Health organization (WHO) declared that, Coronavirus disease 2019 (COVID-19) as worldwide pandemic.[1] This pandemic is an unprecedented emergency that has affected all global industries, including education.[2] Moreover, as a result of social distancing, the most effective preventative strategy since the emergence of COVID-19, [3] medical educations has been profoundly disturbed as it involves in-person didactic lectures and tutorials, clinical rotation exposure, laboratory experiences, observing and assisting relevant medical and surgical procedures. [4]

In this crisis, the need to encourage E-learning in the modern world of education becomes clear. E-learning platforms can be utilized to deliver lectures remotely at one's convenience. Students can then log in at scheduled time for discussions, which can be facilitated live using video and audio conferencing. The online learning has a positive effect if the student participates actively. In high income countries, there is a good experience in distance and online learning in health professional education. [5-7] The situation is differing in low- and middle-income countries, few countries have some experiences in online health professional education, mainly in postgraduates training. $[8,9]$

In response to COVID-19, all universities and colleges in Sudan commanded their students to stay home so the government could handle the situation. Consequently, medical training has been invariably affected; however, few private universities have explored the use of online for academic activities. The effectiveness of these learning platforms in Sudan has been questioned because of poor internet connectivity, relatively expensive out-of-pocket 
spending on internet data bundle and electricity challenges especially in remote rural areas. Moreover, lack of experts and limited access to the online platform are other challenges. This survey was conducted to determine perception of students towards E-learning, the effect of COVID1-19 in education. Additionally, we highlight challenges and difficulties.

\section{Methods}

\section{Study types:}

This descriptive cross-sectional survey study was conducted during 10-25 May 2020 to determine the perception of medical student regard the e-learning, COVID Pandemic and difficulties to reestablish the educational process.

\section{Study population:}

The Total number of students in the faculty was 1700 . The total number of response students was 358 , with different level of education (1st year - 5th year). We include all student who agreed to participate in the survey and exclude who are refused to participate or questionnaire with incomplete data.

\section{Study area:}

The Faculty of Medicine, University of Gezira (FMUG) was established in 1975. It is situated in Wad Medani, the Capital of Gezira State. Though the Faculty of Medicine was established in 1975 the first batch of students was enrolled in 1978 and it is the second oldest medical college in Sudan. Currently there are 42 medical schools in Sudan []. FMUG is the first school adopting the community-oriented, community based and problem-solving strategies in the country and is a pioneer in this innovative type of education all over the globe with social accountability. There has been close collaboration between World Health Organization and the Medical School since its inception.

\section{Study tools}

A predesigned online-based questionnaire was developed by the principle investigator and pilot study was performed. The questionnaire was composed of 16 questions divided into three sections. All questions were labeled with serial number. The data collected sections included: a) Demographic (age, sex, residence, class), b) attitude toward COVID-19, and c) Knowledge, experience and attitude toward online education. The type of questions used included: Yes/No questions, four responses questions in a form of strongly agree, agree, disagree and strongly disagree (modified Likert scale) and open questions. The questionnaire was sent to students' email address and a brief informed consent stated in the opening of the electronic questionnaire.

\section{Data collection and analysis:}

Data were entered and analyzed using SPSS (Statistical Package for Social Science); version 24. Categorical variables are presented as frequencies and percentages and continuous data are presented as means (standard deviation) or median values (range) depending on normality. Chisquare distribution was applied to assess the statistical significance of the effect of sex, level of student, grade, and residence on knowledge/attitude of starting e-learning. $P<0.05$ was considered as statistically significant

\section{Results:}


The total number of participants who agreed to participate in is 358 out of 1700 medical undergraduate students who responded to the survey and filled the electronic questionnaire. The mean age was 20.4 years (SD, 2.07) and ranged between 17-27 years. Female was predominant at 207 (57.8\%). The responders were from all over Sudan; even though $57.5 \%$ are from Gezira state and $8.4 \%$ are residents of other countries. In terms of access to computers, $67.9 \%$ of students had laptops, and $88.5 \%$ of them had a smartphone which used to access the internet. The number of respondents blessed by having static internet services was 145 (40.5\%). The other detailed characteristic of the participant was shown in Table 1.

Table 1

Character of students (Participants) N $=358$

\begin{tabular}{|llll|}
\hline Variables & & Frequency & $\%$ \\
\hline Gender & Female & 207 & 57.8 \\
\hline Residence & Male & 151 & 42.2 \\
\hline & Inside Sudan inside Gezira & 199 & 55.6 \\
\hline & Inside Sudan outside Gezira & 129 & 36.0 \\
\hline Do you have static Internet service? & Outside Sudan & 30 & 8.4 \\
\hline & No & 145 & 40.5 \\
\hline Do you have a laptop? & Yes & 213 & 59.5 \\
\hline & No & 115 & 32.1 \\
\hline Do you have a smart phone with reasonable facility & Yes & 243 & 67.9 \\
\hline & No & 41 & 11.5 \\
\hline
\end{tabular}

The response of students regarding their perceptions and opinions towards the effect of the COVID-19 pandemic in Education, cessation of education, and restart of the educational process was shown in Table 2. The majority $(87.7 \%)$ of students agreed that the closure of the university is an essential decision to control the spread of the COVID-19 infection. On the other hand, $12.3 \%$ of the reported university closure is unnecessary. Approximately two-thirds (64\%) of students agreed that E-learning is the best solution during COVID-19 lockdown. About $79 \%$ agreed and strongly agreed this high time to come back to the faculty. Figure 1 showed a suitable time to start regular learning in the faculty buildings. The level of students in the university (Pre-clerkship and Clerkship) and residence has a strong relation to students' opinions on how to start online education as shown in Table 3. 
Table 2

responses of student regarding starting education:

\begin{tabular}{|c|c|c|c|c|c|}
\hline & $\begin{array}{l}\text { Strongly } \\
\text { agree }\end{array}$ & Agree & Disagree & $\begin{array}{l}\text { Strongly } \\
\text { disagree }\end{array}$ & $\begin{array}{l}\text { Mean } \\
\text { Likert's } \\
\text { score }\end{array}$ \\
\hline $\begin{array}{l}\text { The closure of university is useful to prevent COVID- } \\
19\end{array}$ & $\begin{array}{l}184 \\
(51.4 \%)\end{array}$ & $\begin{array}{l}130 \\
(36.3 \%)\end{array}$ & $\begin{array}{l}29 \\
(8.1 \%)\end{array}$ & $\begin{array}{l}15 \\
(4.2 \%)\end{array}$ & 3.3 \\
\hline The worldwide closure is useful to prevent COVID-19 & $\begin{array}{l}155 \\
(43.3 \%)\end{array}$ & $\begin{array}{l}171 \\
(47.8 \%)\end{array}$ & $\begin{array}{l}24 \\
(6.7 \%)\end{array}$ & $8(2.2 \%)$ & 3.3 \\
\hline $\begin{array}{l}\text { If the distant/online education is started soon, you } \\
\text { will agree and attend the session and exam }\end{array}$ & $\begin{array}{l}117 \\
(32.7 \%)\end{array}$ & $\begin{array}{l}124 \\
(34.6 \%)\end{array}$ & $\begin{array}{l}64 \\
(17.9 \%)\end{array}$ & $\begin{array}{l}53 \\
(14.8 \%)\end{array}$ & 2.9 \\
\hline $\begin{array}{l}\text { This is high time Regarding the continuing of distant } \\
\text { / online education }\end{array}$ & $\begin{array}{l}74 \\
(20.7 \%)\end{array}$ & $\begin{array}{l}167 \\
(49.2 \%)\end{array}$ & $\begin{array}{l}74 \\
(20.7 \%)\end{array}$ & $\begin{array}{l}34 \\
(9.5 \%)\end{array}$ & 2.7 \\
\hline
\end{tabular}

Table 3

Relations of student's level and Residence to closure of university and start of education / E-Learning

\begin{tabular}{|c|c|c|c|c|c|c|c|c|c|}
\hline & & & Level of & udents & & Residence & f Students & & \\
\hline & & total & $\begin{array}{l}\text { Clerk ( } \mathrm{n} \\
=90)\end{array}$ & $\begin{array}{l}\text { Pre-clerk } \\
(\mathrm{n}=268)\end{array}$ & $\begin{array}{l}\mathrm{P} \\
\text { value }\end{array}$ & $\begin{array}{l}\text { Inside } \\
\text { Gezira (n } \\
=199)\end{array}$ & $\begin{array}{l}\text { Outside } \\
\text { Gezira } \\
\text { (n129) }\end{array}$ & $\begin{array}{l}\text { Outside } \\
\text { Sudan } \\
(n=30)\end{array}$ & $\begin{array}{l}\mathrm{P} \\
\text { value }\end{array}$ \\
\hline The closure & Yes & 314 & $84(93.3)$ & $230(85.8)$ & 0.065 & 177(87.9) & $112(86)$ & 25(83.3) & 0.491 \\
\hline $\begin{array}{l}\text { prevent } \\
\text { COVID }\end{array}$ & No & 44 & 6 & 38 & & 22 & 17 & 5 & \\
\hline If the & Yes & 241 & $75(83.3)$ & $166(61.9)$ & 0.001 & $130(65.3)$ & $84(65.1)$ & $27(90)$ & $0.002^{\star}$ \\
\hline $\begin{array}{l}\text { you will agree } \\
\text { and attend } \\
\text { the session } \\
\text { and exams? }\end{array}$ & No & 117 & 15 & 102 & & 69 & 45 & 3 & \\
\hline This is high & Yes & 250 & $74(82.2)$ & $176(65.7)$ & 0.02 & $138(69.3)$ & $87(67.4)$ & $25(83.3)$ & 0.227 \\
\hline $\begin{array}{l}\text { distant / } \\
\text { online } \\
\text { education }\end{array}$ & No & 108 & 16 & 92 & & 61 & 42 & 5 & \\
\hline
\end{tabular}

However, there are 4 factors considered to be against the E-learning implementation as shown in Fig. 2. More than one third (38\%) of the student stated that the good quality internet service is expensive, and the Affordable Internet services are poor in quality. Therefore, it difficult to attend live lectures or download media files. Moreover, in certain areas, due to geographical limitations, the telecommunication signal is quite hampered. $24 \%$ reported that they were unfamiliar with E-learning systems. Approximately $40 \%(n=140)$ were concerned about technical 
support for online sessions and flexibility in case of technical problems during online exams. Eighty-six (24\%) students were concerned about interaction with each other and the instructors during the online session. students.

\section{Discussion:}

The COVID-19 outbreak has forced medical schools to suspend campus learning in order to curb the spread of the virus. Currently, medicals schools in Sudan are closed due to COVID-19 health threat. In such situations, e-learning is the best solution that provides an online interactive learning environment for medical students. Hugenholtz et al. found that e-learning is just as effective in enhancing knowledge as lecture-based learning.[10] In developed world, many academic institutions are using e-learning for more than twenty-years. However, the dominant mode of education around the world is the classic classroom-based interaction. In limited resource countries, like Sudan, shifting towards e-learning require many adjustments to be made in order to make sure the e-learning is held in a proper manner, as best as possible.

In our study, approximately two-third of respondents reported that good quality internet connection is too expensive for them and the affordable bandwidth is limited, which often contributed to slow speed of download and low quality of videos or visual outputs. Moreover, in remote rural areas telecommunication signal is quite hampered. The information on internet infrastructures and availability of computer in our settings may provide baseline information regards challenges to e-learning implementation. In Sub-Saharan Africa inadequate computer facilities, internet connectivity problems, institute experiences of performing e-learning, poor attitudes among students and lecturers, and incompatibility of mobile devices with the university online management systems. [11, 12] A previous study from India reported that 82 out of 201 of the planned e-learning sessions were cancelled due to technical reasons (20\%) or no availability of the presenter at the host end (80\%).[13]

We found $24 \%$ of our study population being hostile to accept e-learning for learning because they are unaware of the effectiveness of e-learning compared to face-face teaching style and are unfamiliar with e-learning systems. Lack of face-to-face interaction was considered as inhibitory factor for e-learning implementation by $15 \%$ of our study population. Therefore, faculty administrator should develop strategies for increasing and ensuring higher levels of students' engagement in and during e-learning. This challenge was reported in several studies from subSaharan Africa. [14-17]

We found most respondents have a smart phone with reasonable facility while only one-third had computers. Therefore, e-learning software that is users-friendly and easy to operate with smart phone is needed. Mobile elearning applications have been developed to provide support for students in rural areas. [18, 19].

We found that $42.4 \%$ of the respondents were worried that e-learning may need specific preparations. Further study is needed to further investigate what factors considered to make them worried in this topic. If lack of understanding on how the e-learning software runs, it means that the information technology staff must educating/socializing in more detail to a more limited and specific group. There is also fear among our study population about the methods for online assessment and time flexibility in case of technical problems.

\section{Conclusion:}

This study can demonstrate the views of perception regard the E-learning after emergency such as COVID-19. Students are willing to continue their learning and educational process. However, there are challenges and 
difficulties which need more analysis to overcome it.

\section{Abbreviations}

FMUG: Faculty of Medicine University of Gezira

\section{Declarations}

\section{Acknowledgements}

Authors acknowledge all participants in the study

\section{Authors' contributions}

MSM, MDAG and MNM conceptualized the study. MSM conducted the data analysis.

MMAA conducted the review of literature. MDAG and MMAA prepared the first draft. All authors contributed to review and revision in the first draft and approved the final version.

\section{Funding}

Not applicable

\section{Availability of data and materials}

Available upon request

\section{Ethics approval and consent to participate}

Ethical approval to conduct the study was obtained from the ethical committee

\section{Consent for publication}

Not applicable

\section{Competing interest}

Authors declare no competing of interest

\section{Declaration}

Authors declare no competing conflict of interest 


\section{References}

1. World Health Organization. Coronavirus disease 2019 (COVID-19): situation report, 72.

2. Ayittey FK, Ayittey MK, Chiwero NB, Kamasah JS, Dzuvor C. Economic impacts of Wuhan 2019-nCoV on China and the world. Journal of Medical Virology. 2020 May;92(5):473-5.

3. Tozzi A, D'Amato G. Cross-reactivity between COVID-19 and childhood vaccines? Electronic response to: del Rio C; Malani PN. 2020. 2019 Novel Coronavirus-Important Information for Clinicians. JAMA. Published online February. 2020;5:2020.

4. Rose S. Medical student education in the time of COVID-19. Jama. 2020 Mar 31.

5. ALGAHTANI A. Evaluating the E ectiveness of the E-learning Experience in Some Universities in Saudi Arabia from Male Students' Perceptions.

6. Kim S. The future of e-learning in medical education: current trend and future opportunity. Journal of educational evaluation for health professions. 2006;3.

7. Means B, Toyama Y, Murphy R, Bakia M, Jones K. Evaluation of evidence-based practices in online learning: A meta-analysis and review of online learning studies.

8. Frehywot S, Vovides Y, Talib Z, Mikhail N, Ross H, Wohltjen H, Bedada S, Korhumel K, Koumare AK, Scott J. Elearning in medical education in resource constrained low-and middle-income countries. Human resources for health. 2013 Dec 1;11(1):4.

9. Frantz JM, Bezuidenhout J, Burch VC, Mthembu S, Rowe M, Tan C, Van Wyk J, Van Heerden B. The impact of a faculty development programme for health professions educators in sub-Saharan Africa: an archival study. BMC medical education. 2015 Dec 1;15(1):28.

10. Hugenholtz NI, De Croon EM, Smits PB, Van Dijk FJ, Nieuwenhuijsen K. Effectiveness of e-learning in continuing medical education for occupational physicians. Occupational Medicine. 2008 Aug 1;58(5):370-2.

11. Adeboye D, van Staden CJ. Difficulties experienced by students using mobile devices to access e-learning. InInternational Conference on Mobile and Contextual Learning 2015 Oct 17 (pp. 351-365). Springer, Cham.

12. Kaliisa R, Picard M. A systematic review on mobile learning in higher education: The African perspective. TOJET: The Turkish Online Journal of Educational Technology. 2017;16(1).

13. Agrawal S, Maurya AK, Shrivastava K, Kumar S, Pant MC, Mishra SK. Training the trainees in radiation oncology with telemedicine as a tool in a developing country: A two-year audit. International Journal of Telemedicine and Applications. 2011 Jan 1;2011.

14. Kheng S. The challenges of upgrading from ISPO Category II level to Bachelor Degree level by distance education. Prosthetics and orthotics international. 2008 Sep;32(3):299-312.

15. Corrêa L, De Campos AC, Souza SC, Novelli MD. Teaching oral surgery to undergraduate students: a pilot study using a Web-based practical course. European Journal of Dental Education. 2003 Aug;7(3):111-5.

16. Akkoyunlu B, Soylu MY. A study of student's perceptions in a blended learning environment based on different learning styles. Journal of Educational Technology \& Society. 2008 Jan 1;11(1):183-93.

17. Muñoz DC, Ortiz A, González C, López DM, Blobel B. Effective e-learning for health professional and medical students: the experience with SIAS-Intelligent Tutoring System. Stud Health Technol Inform. 2010 May 27;156:89-102.

18. Khoja S, Scott RE. Creating e-learning resources in preventive medicine for developing countries. Journal of telemedicine and telecare. 2007 Mar 1;13(2):105-6. 
19. Chang AY, Ghose S, Littman-Quinn R, Anolik RB, Kyer A, Mazhani L, Seymour AK, Kovarik CL. Use of mobile learning by resident physicians in Botswana. Telemedicine and e-Health. 2012 Jan 1;18(1):11-3.

\section{Figures}

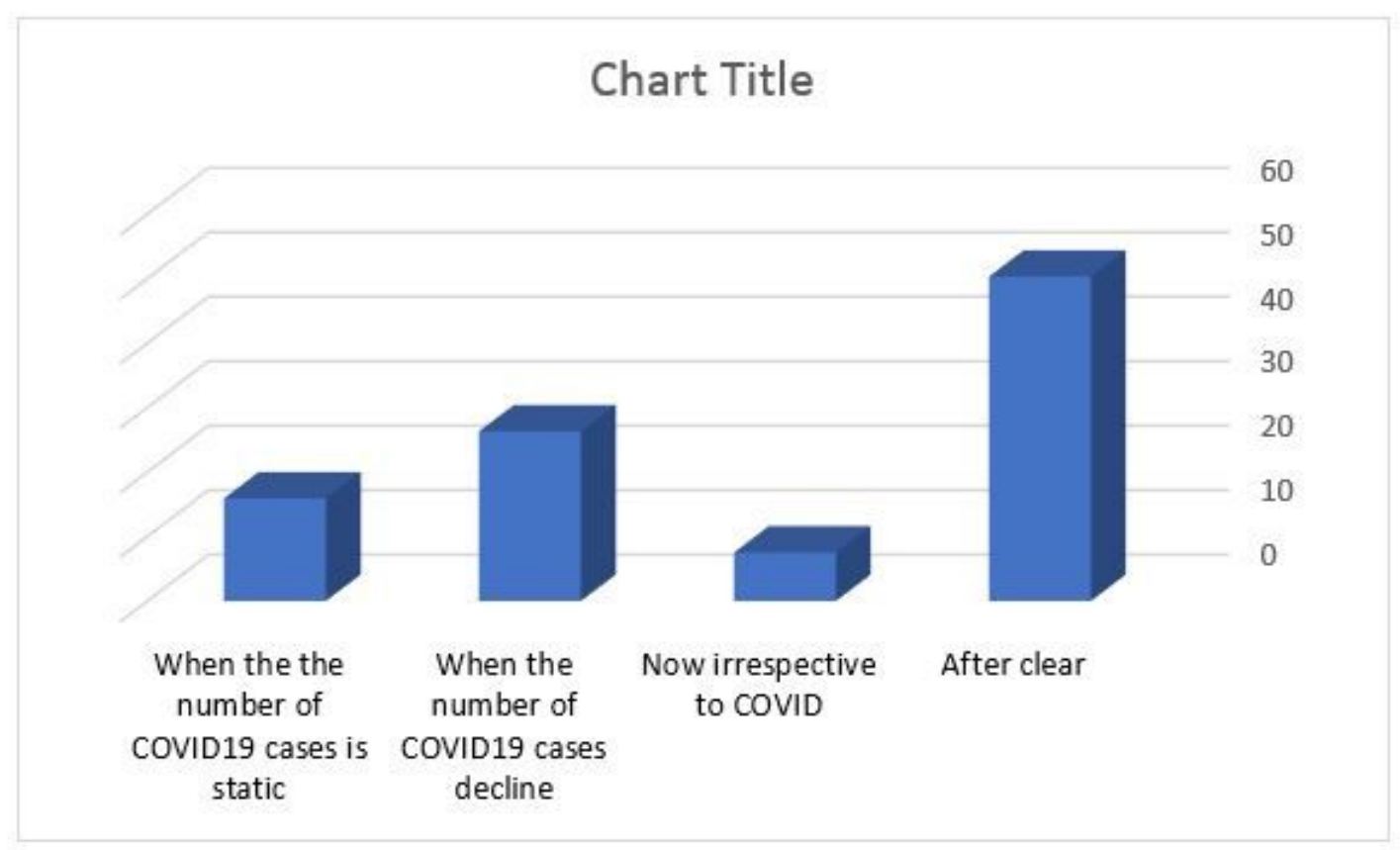

\section{Figure 1}

Students view regarding the suitable time to re-start learning process and open the University

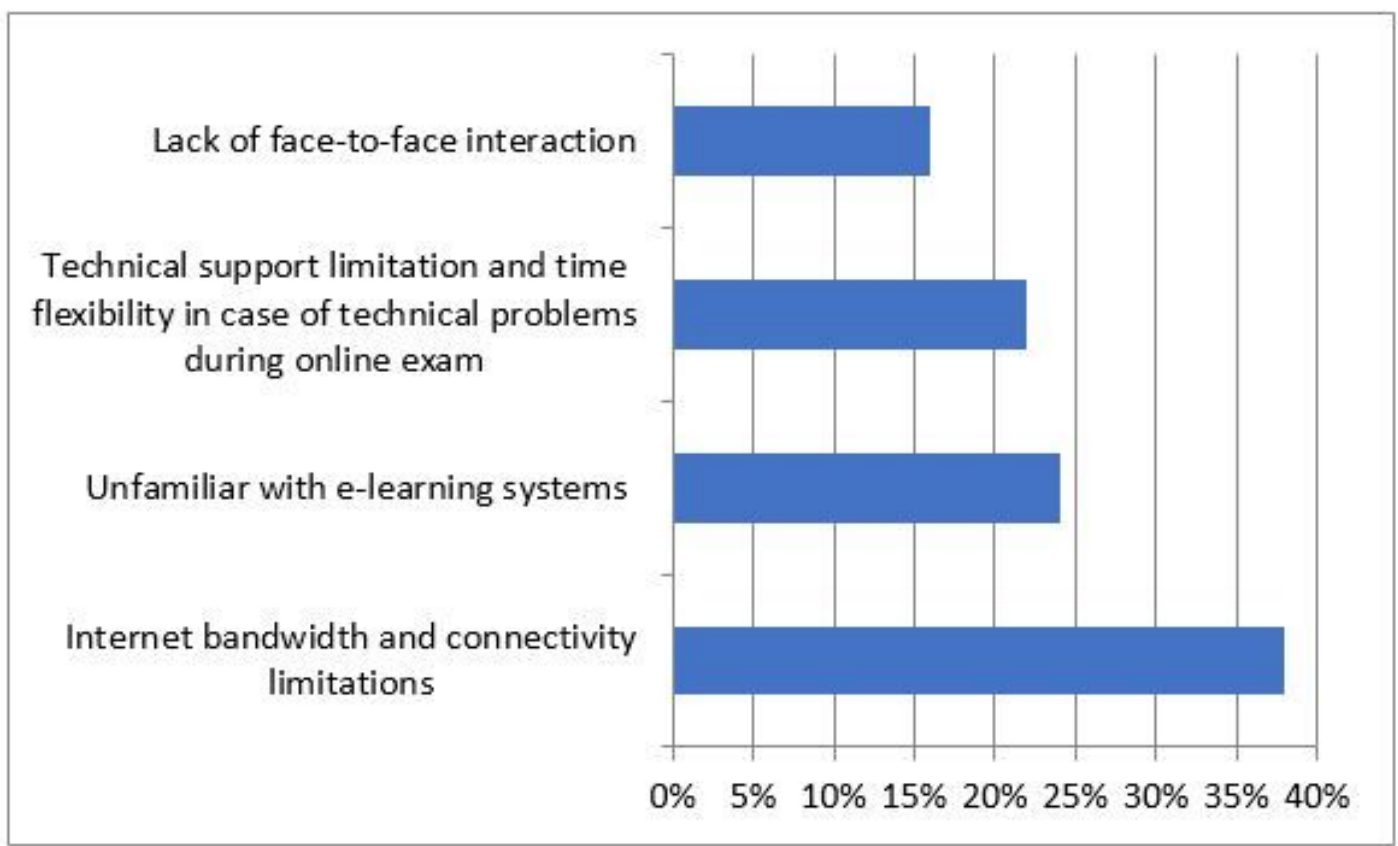

Figure 2 
Students' opinions $(\mathrm{N}=358)$ regarding factors that considered being against the e. learning implementation 